\title{
Els Stronks, Negotiating Differences: Word, Image and Religion in the Dutch Republic
}

(Studies in Medieval and Reformation Traditions 155; Leiden, Boston: Brill, 2011, xx + 341

pp., ISBN 9789004204232 ).

A single, curious image perhaps best encapsulates the contribution of this fascinating book. The title page of Phillipus van Limborgh's Remonstrant 'Christian Theology' (Christelyke godgeleerheid, Fig. 77, 245) features an allegorical woman with a picture of an

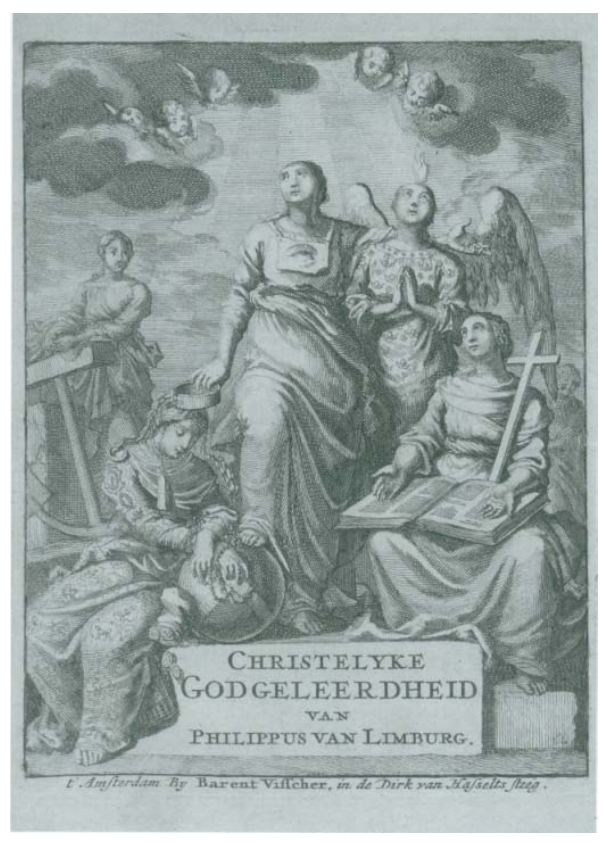
eye on paper around her neck, suspended on her chest like a 'print-necklace' or even ornamental breastplate. Van Limborgh's point (further clarified by Frans de Haas' accompanying poem) still resonates today: the eye, when directed toward God, is a helpful instrument for enhancing faith, and in the hands of Els Stronks, for negotiating doctrinal difference. Stronks' chronological overview of the first century of illustrated religious literature printed in the Northern Netherlands, primarily Bible illustration and religious emblems, reveals patterns of social behavior and confessional identity formation through the long seventeenth century. Moving well beyond a solely iconographical interpretation, what Negotiating Differences offers is no less than a sociology of spiritual practice via the history of reading. But perhaps Stronks' most dramatic achievement is something much less tangible. She grapples hands-on with the messiness of religious change. This is not the neat and fairly predictable tale of the inexorable march of denominational development. Rather, she lets the images tell a much more complicated history of starts and stops, shifting allegiances, misplaced nostalgia, and unresolved tensions that punctuate the tidal swells of confessional diversity, ultimately providing an argument that is as convincing as it is gripping.

'God is in the details', the art historian Aby Warburg famously wrote, and a summary of this book does not do justice to perhaps its greatest strength: it is a treasure trove of carefully gleaned facts. With this caveat in mind, the stage opens with the Dutch Reformed minister Willem Teellinck's 'Ecce Homo, or Eye-salve for Those Who Sit in the 
Blindness of Their Hearts' (Ecce Homo, ofte ooghen-salve voor die noch sitten in blintheydt des ghemoedts, 1622), an exposé of a society's alleged 'blindness' to visually-oriented devotion, itself argued without visual aids! Using this example, in Part One Stronks succinctly presents the disciplinary rationale and socio-historical context for viewing literature as a reflection and catalyst of religious identity, while stressing the dilemma of word-image studies that have traditionally linked issues like the hierarchy of the senses, the empathetic role of images, and the hotly contested realm of visibility with specific confessional beliefs.

Part Two then begins with what can seem like a counter-intuitive stimulus to creative change. The earliest days of illustrated religious print production in the Northern Netherlands, before 1630, were decisively shaped by an increasingly internalized censorship as its awkward Southern Catholic parentage was deliberately obfuscated. Stronks again displays her eye for the telling detail in the experimental iconography of divine presence with arrows that reach disembodied eye and ears (Fig. 9, 62), the austere linear perspective to a Bramantian church (Fig. 15, 82), the representation of intertwined numerals 1 and 3 (Fig. 16, 84), and later, crosses cascading in tandem through the territories of image and text (Fig. 62, 202). Allegorical religious imagery becomes the de facto hero of the story with each community (Dutch Reformed, Anabaptist, Remonstrant and (atholic) finding its own ways to adopt emblematic strategies. Catholics and Protestants were working side by side, but confessional differences initially intensified as each group strove to codify their religious identity, when toleration was conceptualized along the lines of endurance and individualization over our own contemporary associations with acceptance and integration. By the mid-century, the cross-fertilization of models had gone viral - the reuse, or 'spolia', of prints, such as the intriguing rhetorical cross-pollination of Dutch Reformed Protestant and Roman Catholic Jesuit imagery - and Picture Bibles became to a certain degree interconfessional. Stronks also notes the number of illustrated Catholic devotional works published in the Republic from neighboring European countries increased substantially at this time.

The results, or 'Transformations', from crossing boundaries of belief heralded some fairly remarkable new reading patterns of illustrated religious literature by the end of the eighteenth century: the explosion of a truly Dutch Reformed emblem, credited to Jan Luykens, hybridizer par excellence, and a growing demand among Anabaptist, Dutch Reformed children and 'klopje' (celibate Catholic lay women dedicated to serving the Church) audiences. As Northern Catholic devotional imagery began to be published on a scale comparable to pre-revolt numbers, a distinctively Dutch Catholic identity finally emerged. Such conclusions move us far beyond the rigid columnization of the confessional networks of artist, poet and publisher, hardly the most reliable of structures when religious belief was not the sole determinant of social interaction and personal conscience was always in flux, as famously evidenced by Joost van den Vondel and Jan Luykens, if formal affiliation was noted at all. 
Stronks cites the fields of book history, cultural history and visual studies as her primary areas of engagement, and her contributions lie specifically in the social production of emblems, the actual practice of religious toleration and the changing cultures of reading. To say Negotiating Differences does for the Dutch Republic what Tessa Watt's Cheap Print and Popular Piety, 1550-1640 (1991) did for early modern England is true, but neither adequately conveys the radical paradigm shift to a history of confessional connectivity that Stronks presents, nor the fertile tension that derives from the unstable combustibility of word, image and religion, when prints were both active instigators and dynamic repositories for social change. The sheer span, rich sources and admirable clarity of this book will make it essential reading for scholars across the humanities. But what sets apart Negotiating Differences is the way its innovative methodology, interpretation via points of material interaction, consistently disrupts some of the most basic binaries of the early modern world - Catholic and Protestant, word and image, public and private - and thus tenders one eye, one illustrated book, to once again sow the seeds of change.

Mia M. Mochizuki, Jesuit School of Theology, Santa Clara University/ Graduate Theological Union, Berkeley/ University of California, Berkeley 